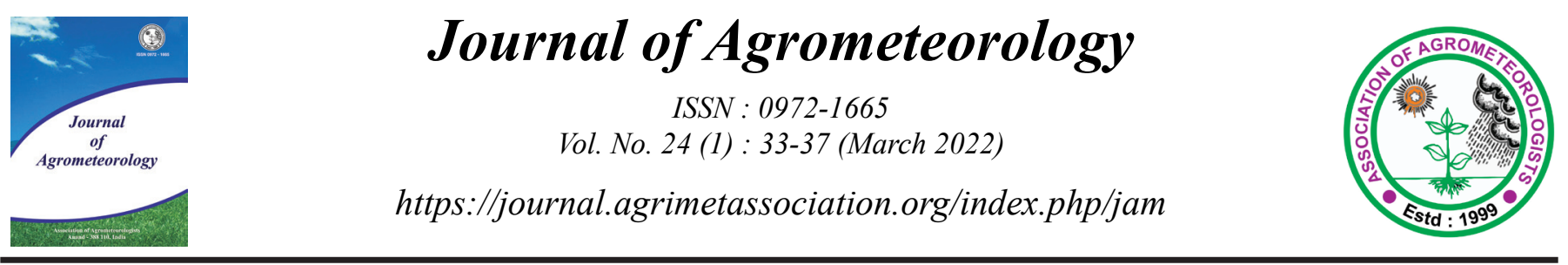

Research Paper

\title{
Assessment of weather effect on flower morphogenesis and fruit set in mango varieties in central India
}

\author{
N.R. RANGARE, MANISH BHAN* and S.K. PANDEY \\ Jawaharlal Nehru Krishi Vishwa Vidyalaya, Jabalpur, India \\ *Corresponding author email : bhan.manish@gmail.com
}

\begin{abstract}
A two-year field experiment was initiated in 2017-18 and 2018-19 to assess the effect of temperature on flower morphogenesis stages, flower sex ratio (hermaphrodite/staminate male flower) and fruit set in monoembryonic Langra and Amrapali varieties. Different dates of flower phenological stages viz., bud, panicle, bloom and flower initiation, pea, marble, egg, and maturity of fruits were recorded. The Langra variety exhibited bud initiation after mid December whereas Amrapali variety by the end of December. The range of mean maximum / minimum temperature as $26-31 / 10-12{ }^{\circ} \mathrm{C}$ promoted hermaphrodite flowers per panicle by 74 per cent in Langra variety, whereas range of $27-29 / 11-13{ }^{\circ} \mathrm{C}$ favored by 35 per cent in Amrapali variety. A positive and significant correlation between total number of flower / panicle and flower sex ratio in both the varieties suggested that higher temperature during initial flower phenologies improved number of hermaphrodite flowers. A mean minimum temperature for producing more number of hermaphrodite flower exhibited a range of $11-14{ }^{\circ} \mathrm{C}$ under central Indian conditions. Fruit set was maximum during pea stage and decline afterwards in marble and fruit maturity stages due to sudden rise in temperature at marble stage that caused in drop down of humidity thereby resulted in fruit drop in both the varieties.
\end{abstract}

Key words: Mango flower morphogenesis, temperature, flower sex ratio, fruit set

Mango (Mangifera indica L., Anacardiaceae) is a major fruit of tropical and subtropical climate, and suited well to climatic conditions of central India. Environmental factors like temperature and humidity affects the process of flowering in mango besides nutritional and hormone factors (Parmar et al., 2012). It is anticipated to understand flowering time to efficiently utilize cropping management systems that extend both flowering and crop production seasons (Ramírez and Davenport, 2010). In the subtropics, floral morphogenesis initiated during cool weather with minimum temperature of $15^{\circ} \mathrm{C}$ or lower, however vegetative morphogenesis initiated if temperature exceed above $20^{\circ} \mathrm{C}$ (Nunez and Davenport, 1991). Many studies suggested that variation in minimum temperature affect low fruit set, high fruit drop and influence pollen development under sub-tropical latitude prevalent in central Indian conditions (Sukhvibul et al., 1999). A cool temperature reduces hermaphrodite flowers while warm temperature increase it (Singh and Sharma, 1972). Mango varieties adopted to south Indian conditions showed higher sex ratio of hermaphrodite to male staminate flowers than of north Indian conditions like Langra and Amrapali varieties due to variation in temperatures (Geetha et al., 2016).

A fewer work has been reported on the mango-weather association for central India conditions particularly related to flowering stages and inflorescence development, and variability in sex ratio at the time of flowering to get uniform fruit set and yield. It is anticipated to have more significance due to climatic change scenario causing an increase in the number of weather anomalies like irregular rainfall distribution, reduced minimum temperature, etc during flower initiation in mango. Many varieties are showing staggered flowering due to these climatic aberrations (Geetha et al., 2016, Chavan et al., 2020). The present study was conducted to assess the influence of major weather parameters on floral morphogenesis, identify varieties that show variability in flower sex ratio or assessing hermaphrodite flowers with respect to temperature and fruit set using two varieties with monoembryonic nature grown commercially in central India.

Article info - DOI: https://doi.org/10.54386/jam.v24i1.773

Received: 12 April 2021; Accepted: 6 January 2022; Published online: 11 February 2022

This work is licenced under a Creative Common Attribution 4.0 International licence@Author(s),Publishing right @ Association of Agrometeorologists 


\section{MATERIALS AND METHODS}

The study was carried out at Horticultural research orchard at Jawaharlal Nehru Krishi Vishwa Vidyalaya, Jabalpur, Madhya Pradesh from September to June months during the 2017-18 and 2018-19. The research experiment was geographically located at $23^{\circ} 18^{\prime} \mathrm{N}$ latitude, $79^{\circ} 98^{\prime} \mathrm{E}$ longitude and $411 \mathrm{~m}$ above mean sea level. The different weather parameters range viz., maximum temperature from 24.7 to $42.9{ }^{\circ} \mathrm{C}$, minimum temperature from 3.9 to $28.6{ }^{\circ} \mathrm{C}$, wind speed from 2.3 to $7.8 \mathrm{kmph}$, and a total rainfall of $459 \mathrm{~mm}$ in the year 2017-18. Similarly in 2018-19 year, maximum temperature range from 19.6 to $44.4{ }^{\circ} \mathrm{C}$, minimum temperature from 3.1 to $27.3{ }^{\circ} \mathrm{C}$, wind speed at 1.8 to $7.0 \mathrm{kmph}$, and a total rainfall of $624 \mathrm{~mm}$. The present study were conducted on most common growing two monoembryonic varieties viz., Langra (biennial irregular bearer) and Amrapali (regular bearer) as grown extensively in central India. Weather sensors (WatchDog ${ }^{\circledR}$ button loggers, T/RH , Spectrum Technol. Inc, USA) were put inside radiation shield and placed under the trees at $3 \mathrm{~m}$ above the ground surface to record temperature, relative humidity and dew point at hourly intervals. The other weather parameters viz., wind speed dataset were collected from surface meteorological observatory located at $200 \mathrm{~m}$ distance from the orchard. The reproductive growth stages starting from bud, panicle, first bloom, first flower open, pea, marble, egg, and maturity of fruit stages were recorded by virtually observing the tagged plants among both the varieties. Additionally, the other parameters like number of male staminate and hermaphrodite flowers were also recorded during the month of February in both the years during peak flowering season. Panicles were tagged randomly on entire plant for counting, with a total of five flower panicles per tree from ten trees of each variety. Hermaphrodite and male flowers were counted, and their mean number were used, as suggested by Geetha et al.,(2016). Fruit yield (kg/plant) were calculated by picking mature fruits from each tree of both the varieties. Yield of more than $50 \mathrm{~kg} /$ plant was used for analysis. Weather and crop datasets from two years were pooled for analysis of crop-weather relationship. A flower sex ratio (proportion of hermaphrodite to staminate flowers per panicle) and total number of flowers per panicle were correlated to understand the relationship between the size of the panicle and the number of flowers per panicle using MS Excel 2007 and SPSS (version 20) programmes. The flower sex ratio was plotted against mean minimum temperature of 30 days of January month or monthly dataset used two weeks before flower initiation for assessing response of optimum temperature on hermaphrodite flower production. Flower sex ratio data was pooled for two years with minimum temperature, as few flower panicles were available during January month. Later, daily temperature data were averaged into weekly data and related with sex ratio. At the end, fruit set (percent of fruit per hermaphrodite flower) per panicle was observed at different floral phenological stages (pea, marble and fruit maturity) to assess fruit numbers that sustain till harvest among both the varieties.

\section{RESULTS AND DISCUSSION}

\section{Weather parameters and floral phenological stages}

The weather parameters at different floral morphogenesis were observed with their occurrence time in Langra (Table 1) and
Amrapali (Table 2) varieties. The Langra variety exhibited floral bud initiation from December 31 in 2018 while it occurred on December 12 in 2019 . The maximum temperature from floral initiation to fruit maturity observed in a range of 16.6 to $46{ }^{\circ} \mathrm{C}$ whereas a minimum temperature ranges between 1.6 to $32.6^{\circ} \mathrm{C}$. A first bloom followed by flower initiation occurred during February month where maximum temperature ranged between $16-30^{\circ} \mathrm{C}$ while minimum temperature ranged from of $2-16{ }^{\circ} \mathrm{C}$. There was an inverse relationship between length of anthesis period and temperature (Sukhvibul et al., 2000). A pea stage occurred in the first fortnight of March month where maximum and minimum temperature ranged between 25 to 36 and 8 to $18{ }^{\circ} \mathrm{C}$, respectively. A marble stage occurred during the end of March to first week of April with 26 to 41 and 9 to $19^{\circ} \mathrm{C}$ as range of maximum and minimum temperatures, respectively. While the fruit matured in the first week of June the range of 37 to $46{ }^{\circ} \mathrm{C}$ as maximum temperature while 21 to $32{ }^{\circ} \mathrm{C}$ as minimum temperature. The morning and evening relative humidity and dew point under the canopy along with wind speed was also observed and presented in the Table 1.

In Amrapali variety, bud was initiated on December 26 in 2018 while December 31 in 2019. A maximum temperature ranged between 17 to $46^{\circ} \mathrm{C}$ and minimum temperature ranged from 4 to $32{ }^{\circ} \mathrm{C}$, from floral initiation to fruit maturity. A pea size fruit occurred in the first week of March where maximum and minimum temperature ranged from 24 to 35 and 9 to $18{ }^{\circ} \mathrm{C}$, respectively. Similarly at marble stage occurred in the first week of April, a range of maximum and minimum temperature was 25 to 40 and 12 to $23^{\circ} \mathrm{C}$. While fruit matured occurred in the second week of June with maximum and minimum temperature ranged between 34 to 46 and 20 to $32^{\circ} \mathrm{C}$. The morning and evening relative humidity, morning and evening dew point and wind speed were also assessed at different floral morphogenesis stages of this variety in the Table 2.

The morning and evening relative humidity, low to high values of dew point temperature under the tree canopy decrease with an increase in maturity period among both the varieties (Tables 1 and 2). Similarly, wind speed of the atmosphere also increased with an increase in maturity period. This may be due to rise in the temperature that caused changes in the other weather parameters. There is not much differences in these parameters in both the varieties hence, results suggested that higher relative humidity and dew point in the beginning of floral morphogenesis period enhanced total number of flowers, whereas low wind speed at early flower stages may reduced fruit drop in mango. As these parameters are dependent on temperature differences and variation in vapour pressure, they may not affect much floral morphogenesis in mango as compared to air temperature.

\section{Flower sex ratio - temperature relationship}

Male staminate and hermaphrodite flowers, floral sex ratio and its influence by temperature, their correlations, and mean fruit yield were mentioned in the Table 3. The number of hermaphrodite flower was more than male staminate flower in Langra variety that result in higher fruit yield than Amrapali variety. Langra variety produces maximum hermaphrodite flowers that directly contributes for better fruit set and fruit production indicating the strong genetic 
Table 1: Weather parameters threshold (pooled) at different flower phenological stages in Langra variety

\begin{tabular}{|c|c|c|c|c|c|c|c|c|c|c|c|c|c|c|c|}
\hline $\begin{array}{l}\text { Flower phenological } \\
\text { stages }\end{array}$ & $\begin{array}{l}\text { Time of } \\
\text { occurrence } \\
\text { (days) }\end{array}$ & \multicolumn{2}{|c|}{$\begin{array}{l}\text { Maximum } \\
\text { temp } \\
\left({ }^{\circ} \mathrm{C}\right)\end{array}$} & \multicolumn{2}{|c|}{$\begin{array}{l}\text { Minimum } \\
\text { temp } \\
\left({ }^{\circ} \mathrm{C}\right)\end{array}$} & \multicolumn{2}{|c|}{$\begin{array}{l}\text { RH morning } \\
(\%)\end{array}$} & \multicolumn{2}{|c|}{$\begin{array}{l}\text { RH evening } \\
(\%)\end{array}$} & \multicolumn{2}{|c|}{$\begin{array}{l}\text { Dew point } \\
\text { temp } \\
\text { morning } \\
\left({ }^{\circ} \mathrm{C}\right)\end{array}$} & \multicolumn{2}{|c|}{$\begin{array}{l}\text { Dew point } \\
\text { temp } \\
\text { evening } \\
\left({ }^{\circ} \mathrm{C}\right)\end{array}$} & \multicolumn{2}{|c|}{$\begin{array}{l}\text { Wind speed } \\
(\mathrm{kmph})\end{array}$} \\
\hline Bud- Panicle & 27 & 20.6 & 28.6 & 1.6 & 11.6 & 82.1 & 100 & 24.2 & 57.1 & 1.5 & 12.2 & 0.9 & 12.3 & 1.6 & 5.1 \\
\hline Panicle - I st bloom & 10 & 16.6 & 30.6 & 2.6 & 16.6 & 72.2 & 100 & 19.5 & 93.7 & 2.6 & 16.7 & 0.9 & 17.6 & 1.9 & 7.1 \\
\hline Pea- Marble & 25 & 26.1 & 41.0 & 9.1 & 19.1 & 63.6 & 98.7 & 15.1 & 64.2 & 7.9 & 21.8 & 1.9 & 21.8 & 1.9 & 7.2 \\
\hline Marble- Egg & 40 & 30.6 & 43.0 & 16.1 & 24.6 & 34.1 & 100 & 7.9 & 63.1 & 6.8 & 20.1 & 1.1 & 19.9 & 2.0 & 7.9 \\
\hline Egg-Maturity & 59 & 37.6 & 46.0 & 21.6 & 32.6 & 28.9 & 79.4 & 8.8 & 35.2 & 8.7 & 20.1 & 2.8 & 18.2 & 2.6 & 9.3 \\
\hline
\end{tabular}

Table 2: Weather parameters threshold (pooled) at different flower phenological stages in Amrapali variety

\begin{tabular}{|c|c|c|c|c|c|c|c|c|c|c|c|c|c|c|c|}
\hline $\begin{array}{l}\text { Flower phenological } \\
\text { stages }\end{array}$ & $\begin{array}{l}\text { Time of } \\
\text { occurrence } \\
\text { (days) }\end{array}$ & \multicolumn{2}{|c|}{$\begin{array}{l}\text { Maximum } \\
\text { temperature } \\
\left({ }^{\circ} \mathrm{C}\right)\end{array}$} & \multicolumn{2}{|c|}{$\begin{array}{l}\text { Minimum } \\
\text { temperature } \\
\left({ }^{\circ} \mathrm{C}\right)\end{array}$} & \multicolumn{2}{|c|}{$\begin{array}{l}\text { Relative } \\
\text { humidity } \\
\text { morning } \\
(\%)\end{array}$} & \multicolumn{2}{|c|}{$\begin{array}{l}\text { Relative } \\
\text { humidity } \\
\text { evening } \\
(\%)\end{array}$} & \multicolumn{2}{|c|}{$\begin{array}{l}\text { Dew point } \\
\text { temperature } \\
\text { morning } \\
\left({ }^{\circ} \mathrm{C}\right)\end{array}$} & \multicolumn{2}{|c|}{$\begin{array}{l}\text { Dew point } \\
\text { temperature } \\
\text { evening } \\
\left({ }^{\circ} \mathrm{C}\right)\end{array}$} & \multicolumn{2}{|c|}{$\begin{array}{l}\text { Wind speed } \\
(\mathrm{kmph})\end{array}$} \\
\hline Bud- Panicle & 25 & 21.1 & 31.1 & 4.0 & 14.6 & 71.1 & 100 & 22.6 & 58.3 & 3.4 & 12.9 & 2.6 & 17.4 & 1.6 & 4.3 \\
\hline Panicle - I st bloom & 8 & 17.1 & 31.6 & 4.0 & 17.1 & 75.6 & 100 & 19.9 & 68.3 & 4.4 & 14.9 & 1.9 & 20.2 & 1.9 & 7.1 \\
\hline I st bloom- Ist flower & 16 & 20.1 & 35.1 & 9.0 & 19.1 & 89.1 & 100 & 22.6 & 60.7 & 10.0 & 17.9 & 7.2 & 19.9 & 1.9 & 4.5 \\
\hline Pea- Marble & 28 & 25.6 & 40.0 & 12.0 & 23.1 & 44.8 & 99.7 & 6.0 & 60.6 & 8.8 & 18.2 & 4.5 & 20.9 & 1.9 & 7.3 \\
\hline Marble- Egg & 43 & 30.1 & 42.0 & 15.1 & 26.1 & 32.8 & 99.2 & 6.0 & 62.4 & 7.1 & 19.6 & 3.4 & 20.2 & 2.4 & 7.9 \\
\hline Egg-Maturity & 54 & 34.1 & 46.1 & 20.6 & 32.1 & 28.7 & 90.7 & 6.0 & 67.1 & 7.9 & 54.1 & 1.5 & 19.2 & 3.1 & 9.9 \\
\hline
\end{tabular}

Table 3: Male and hermaphrodite flowers per panicle, sex ratio, mean maximum and minimum air temperatures during inflorescence, and correlation coefficients (r) between total number of flower/panicle and flower sex ratio of mango varieties

\begin{tabular}{|c|c|c|c|c|c|c|c|}
\hline Varieties and year & $\begin{array}{l}\text { Male } \\
\text { staminate }(\%)\end{array}$ & $\begin{array}{l}\text { Hermaphrodite } \\
(\%)\end{array}$ & $\begin{array}{l}\text { Sex } \\
\text { ratio* }\end{array}$ & $\begin{array}{l}\text { Mean } \\
\text { maximum } \\
\text { temperature } \\
\left({ }^{\circ} \mathrm{C}\right)^{* *}\end{array}$ & $\begin{array}{l}\text { Mean minimum } \\
\text { temperature }\left({ }^{\circ} \mathrm{C}\right)^{* *}\end{array}$ & $\begin{array}{l}\text { Corr. Coeff. } \\
\text { (r) }\end{array}$ & $\begin{array}{l}\text { Fruit yield }(\mathrm{kg} / \\
\text { plant) }\end{array}$ \\
\hline Langra (2018-19 & 25.6 & 74.3 & 2.91 & 26.3 & 10.0 & $(\mathrm{P}=0.002)$ & 72 \\
\hline Amrapali (2017-18) & 64.3 & 35.6 & 0.56 & 27.2 & 11.8 & 0.79 & 53 \\
\hline
\end{tabular}

* Sex ratio is a proportion of number of hermaphrodite to male staminate flowers.

** Temperature datasets observed at the time of panicle inflorescence during February months in both the years

control of the character (Kobra et al., 2012).

In February month, a proportion of maximum/minimum temperatures were $26-31 / 10-12{ }^{\circ} \mathrm{C}$ produced higher number of hermaphrodite than male flowers in Langra variety. In the same month, a proportion of $27-29 / 11-13.7^{\circ} \mathrm{C}$ range of maximum/ minimum temperatures produced higher number of male than hermaphrodite flowers in Amrapali variety. It is reported that low temperatures $\left(10-15^{\circ} \mathrm{C}\right.$ or below $\left.15^{\circ} \mathrm{C}\right)$ during flowering increased the proportion of staminate flowers while high temperature increased hermaphrodite flowers (Ramírez and Davenport, 2010; Geetha et al., 2016). A day/night temperature at $30 / 20{ }^{\circ} \mathrm{C}$ generally increased inflorescence size and decreased mean number of flowers per inflorescence (Sukhvibul et al., 1999). The proportion of hermaphrodite to male staminate flowers was also found to be influenced by the size of flower panicle. The relationship between size of the panicle (total number of flowers per panicle) and floral sex ratio was assessed with significant and positive correlation exhibited among both the varieties (Table 3). It suggest that both these varieties have more or less uniform inflorescence in terms of total number of flowers, hence variation in sex ratio between the inflorescences was also negligible (Geetha et al., 2016). The fruit yield per plant was also assessed among both the varieties for twoyear simultaneously (Table 3 ). The 2017-18 year as off-bearing year for Langra variety that resulted in fewer fruit yield. The on-bearing year produced a good fruit yield and was higher than Amrapali variety. Similarly, Amrapali variety is a regular bearer produced similar fruit yield per plant among both the years at Jabalpur location in eastern Madhya Pradesh state of India. 


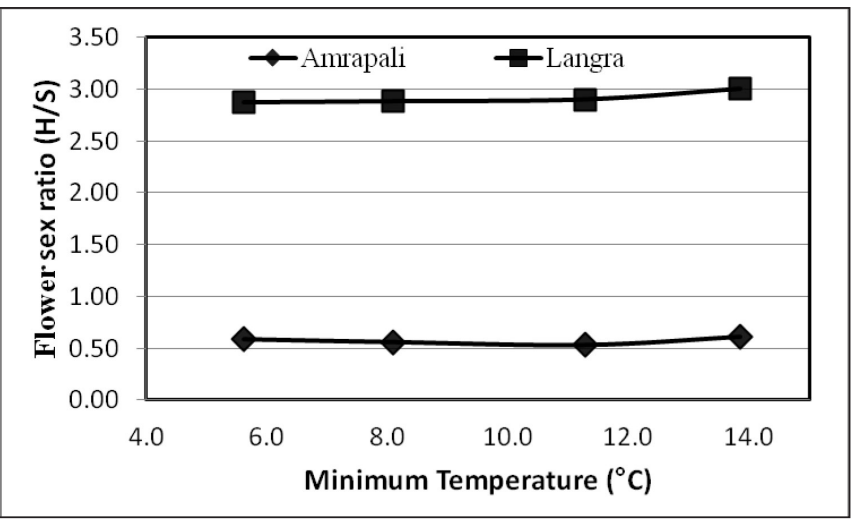

Fig. 1: Relationship between flower sex ratio (hermaphrodite to Staminate $\mathrm{H} / \mathrm{S}$ ) and mean minimum temperature during floral stages in Langra and Amrapali varieties in central India. Minimum temperature during panicle to bloom initiation period were used as two weeks before flower emergence

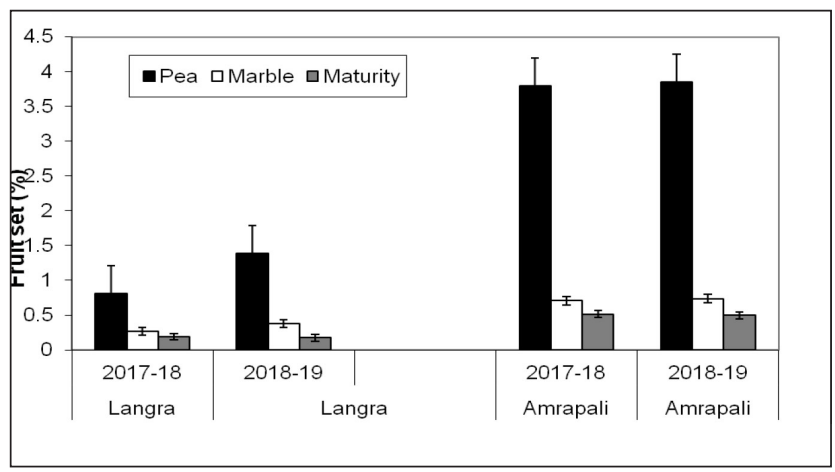

Fig. 2: Fruit set as percent of fruit number per hermaphrodite flower per panicle at different floral morphogenesis stages in mango varieties. (Data of hermaphrodite was obtained during February month in both the years)

\section{Flower sex ratio and mean minimum temperature}

The mean minimum temperature was calculated during panicle to bloom initiation stages occurred majorly during January month. It is plotted against floral sex ratio and shown in the Fig.1. A positive significant relationship between temperature and panicle emergence was observed two weeks before flower emergence. The result indicated that the mean minimum temperature range of 11 $14{ }^{\circ} \mathrm{C}$ for production of maximum proportionate of hermaphrodite flowers among both the varieties at Jabalpur. A lower temperature of $15.5^{\circ} \mathrm{C}$ was required for Langra and $16{ }^{\circ} \mathrm{C}$ for Amrapali varieties for maximum hermaphrodite flower production under south Indian conditions (Geetha et al., 2016). The variation in temperature at different locations may be related to their place of origin. Langra variety is popularly grown under north Indian conditions, and may have ability to produce more hermaphrodite flowers even at low temperature. Sometimes, low temperature of $20 / 10{ }^{\circ} \mathrm{C}$ decreased the percent of hermaphrodite flowers in polyembryonic varieties however flower increased the percent in monoembryonic varieties (Sukhvibul et al., 2000). Overall, low temperature exposure is a major variable in determining flower sex ratio as low temperature during floral morphogenesis period that occurred much before flower emergence is crucial for proportion of hermaphrodite flower in mango (Whiley, et al., 1995).

\section{Fruit set and floral phenological stages}

Fruit set as percent of fruit formed from hermaphrodite flowers during pea, marble and maturity stages exhibited Amrapali variety with higher fruit set percent than Langra variety (Fig. 2). This may be due to varietal characteristics with regular bearing in Amrapali whereas Langra with biennial irregular bearing habits. The fruit set was greater during pea stage in the month of March and getting reduced as fruit reached maturity with higher in Amrapali than Langra variety. This is due to the occurrence of fruit drop in both the varieties. The fruit drop may be due to sudden rise in the temperatures during pea to marble stages that caused a drop down of humidity. Due to this, young fruit could not stand and ultimately fall from the tree. This results were similar to the findings of Salvi et al. (2013) and Thompson and Liu (1973). The Amrapali variety observed lower hermaphrodite flowers than Langra variety as showed in the Table 3, however it produced more percent of fruit set, particularly during pea stage as shown in the results. This may be due to higher temperature during March month as fruit set is influenced by the proportion of hermaphrodite flowers (Iyer et al., 1989). Geetha et al. (2016) too suggested that the temperature was found to have a significant role in fruit set as flower initiation started during February months exhibited a good fruit set in spite of few hermaphrodite flower percent that initiated during January months due to the temperature levels more during February than January months.

\section{CONCLUSION}

The study will be helpful to understand the role of weather parameters especially maximum and minimum temperature on flower biology in improving fruit yield under central Indian conditions. It is also important to identify flower morphogenesis period in order to assess relationship between the temperature and proportion of hermaphrodite to staminate male flowers. At the end, fruit set is influenced by rise in temperature and humidity during pea to marble stage that resulted in fruit drop of the plant. Overall, the result suggested that both maximum and minimum temperature play an important role in the hermaphrodite flower proportion and fruit set among both the monoembryonic varieties grown under central Indian conditions.

\section{ACKNOWLEDGEMENTS}

The corresponding author is thankful to Dr. Kanchan S. Bhan, Assistant Professor (Biotechnology), IGKV, Raipur in reviewing the manuscript. The study was conducted jointly under the AICRP on Agrometeorology (ICAR) and Department of Horticulture, JNKVV, Jabalpur and the necessary facilities and technical assistance provided for the study is due fullyacknowledged

Conflict of Interest Statement: The author(s) declare(s) that there is no conflict of interest. 
Disclaimer: The contents, opinions and views expressed in the research article published in Journal of Agrometeorology are the views of the authors and do not necessarily reflect the views of the organizations they belong to.

Publisher's Note: The periodical remains neutral with regard to jurisdictional claims in published maps and institutional affiliations.

\section{REFERENCES}

Chavan, V.G., Rajemahadik, V.A., More,V.G., Chavan, S.A. and Mahadkar,U.V. (2020). Weather based prediction model for time of occurrence of vegetative flush in mango cv. Alphonso for Konkan region of Maharashtra state. $J$. Agrometeorol., 22 (4):531-533.

Geetha, G.A., Shivashankara, K.S., and Reddy, Y.T.N. (2016). Varietal variations in temperature response for hermaphrodite flower production and fruit set in mango. South African J. Bot. 106:196-203.

Iyer, C.P.A., Subbiah, M.C., Subramanyam, M.D., and Rao, G.S.P. (1989). Screening of germplasm and correlation among certain characters in mango. Acta Hortic., 231:83-90.

Kobra, K., Hossain, M.A., Talukder, M.A.H., and Bhuyan, M.A.J. (2012). Performance of twelve mango cultivars grown in different agro-ecological zones of Bangladesh. Bangladesh J. Agric. Res., 37:691-710.

Nunez-Elisea ,R. and Davenport, T.L. (1991). Effect of duration of low temperature treatment on flowering of containerized 'Tommy Atkins' mango. Hort. Sci., 26: 751.
Parmar, V.R., Shrivastava, P.K. and Patel, B.N. (2012). Study on weather parameters affecting mango flowering in south Gujarat. J. Agrometeorol., (Spl. Issue) 14:351-353.

Ramírez, F. and Davenport, T.L. (2010). Mango flowering physiology. Sci. Hortic., 126:65-72.

Salvi, B.R., Damodhar, V.P., Mahaldar, S.R. and Munj, A.Y. (2013). Effect of high temperatures on fruit drop and spongy tissue in alphonso mango. Ann. Plant Physiol., 27:5-10.

Singh, R.N. and Sharma, D.K. (1972). Some pollination problems in mango. Acta Hortic. 24:134-138.

Sukhvibul, N., Whiley, A.W., Smith,M. K., Hetherington, S.E., and Vithanage, V. (1999). Effect of temperature on inflorescence and floral development in mango. Scientia Hort., 82:67-84.

Sukhvibul, N., Hetherington, S.E., Whiley, A.W., Smith, M.K. and Vithanage, V. (2000) Effect of temperature on inflorescence development and floral biology of Mango (Mangifera indica L.). ISHS Acta Hort., 509: 601:605.

Thompson, M.M and Liu, L.J. (1973). Temperature, fruit set and embryo sac development in 'Italian' prune. J. Am. Soc. Hort. Sci., 98:193-197.

Whiley, A.W., Rasmussen, T.S., Saranath, J.B. and Wolstenholmv, B.N. (1995). Effect of temperature on growth, dry matter production and starch accumulation in ten mango cultivars. J. Hort. Sci. Biotechnol., 64:97-104. 